\title{
Proses Berpikir Mahasiswa Jurusan PG-PAUD dalam Memecahkan Masalah Matematika dengan Scaffolding ditinjau Gaya Kognitif
}

\author{
(The Thinking Process of The Department Early Childhood Education student, Halu Oleo \\ University Solving Mathematic Problem with Scaffolding in the Perspective of Different \\ Cognitive Style)
}

\author{
Damsir Dima ${ }^{1}$, Muhammad Sudia ${ }^{2}$, Hafiludin Samparadja ${ }^{2}$ \\ ${ }^{1}$ Alumnus Prodi Pendidikan Matematika PPs Universitas Halu Oleo \\ ${ }^{2}$ Dosen Pendidikan Matematika FKIP dan PPS Universitas Halu Oleo; Co-author: \\ muhamad_matematika@yahoo.co.id
}

\begin{abstract}
Abstrak: Penelitian ini bertujuan untuk mengungkap proses berpikir mahasiswa jurusan PGPAUD FKIP UHO dalam memecahkan masalah matematika dengan Scaffolding ditinjau dari gaya kognitif. Jenis penelitian ini adalah penelitian deskriptif-kualitatif. Subjek penelitian ini diperoleh melalui test (Matching Familiar Figure Test) MFFT. Instrumen utama penelitian ini adalah peneliti, dan instrumen bantu adalah test gaya kognitif (MFFT), tugas pemecahan masalah, dan pedoman wawancara. Berdasarkan hasil analisis data dan pengamatan dalam penelitian diketahui bahwa: 1) pada tahap memehami masalah proses berpikir kedua subjek cenderung konseptual, 2) pada tahap merencanakan penyelesaian proses berpikir kedua subjek cenderung konseptual, 3) pada tahap melaksanakan rencana, subjek impulsif terburu-buru menyelesaikan masalah, sehingga penyelesaiannya cenderung salah, namun dengan scaffolding mampu menyelesaikan masalah dengan benar. Pada tahap ini proses berpikir subjek impulsif cenderung konseptual. Sedangkan subjek Reflektif terhenti ketika menyelesaikan masalah tetapi setelah diberikan scaffolding mampu menyelesaikan masalah dengan benar. Pada tahap ini proses berpikir subjek reflektif cenderung semikonseptual, 4) Tahap memeriksa kembali, proses berpikir kedua subjek cenderung konseptual.
\end{abstract}

Kata kunci: Proses Berpikir Matematika, Gaya Kognitif, Scaffolding, Pemecahan Masalah Matematika.

\begin{abstract}
This research aims to reveal the thinking process of The Department Early childhood Education students in Halu Oleo University in solving math problems with scaffolding in terms of cognitive. This research used descriptive-qualitative. The subject of this research was obtained through MFFT (Matching Familiar Figure Test) test. The main instrument of this research was the researcher itself and the auxiliary instrument were cognitive style test of MFFT, problem-solving tasks, and interview guides. Based on the result of data analysis and observation known that: 1) in the stage of understanding the problem, both subjects the thinking process tend to conceptually, 2) in the completion planning stage, both subjects the thinking process tend to conceptually, 3 ) in the stage of implementing, impulsive subjects were hurry to solve the problem, so the solution tends to be wrong but with scaffolding they are able to finish properly. In this stage, impulsive subjects tend to think conceptually. While the reflective subjects are stop solving the problem, but after being given scaffolding was able to solve the problem correctly. The impulsive subjects tended to think semi conceptual, 4) the crosscheck stage, both of subjects tended to think conceptually.
\end{abstract}

Keywords: Mathematical Thinking Process, Cognitive Style, Scaffolding, Problem Solving

\section{PENDAHULUAN}

Pemecahan masalah merupakan
bagian yang terpenting dalam
pembelajaran matematika. Salah satu
bentuk pengorganisasian pemecahan
masalah matematika sebagaimana
dikemukakan Polya (1973) yang meliputi
4 langkah, yakni: (1) memahami masalah;
(2) menentukan rencana pemecahan
masalah; (3) mengerjakan sesuai rencana;

(4) melihat kembali hasil yang diperoleh. Melalui langkah-langkah pemecahan masalah yang dikemukakan Polya di atas memungkinkan terlaksananya pemecahan masalah yang sistematis dan hasilnya tidak saja berupa pemecahan yang benar, tetapi juga terbentukya pola pikir yang terstruktur dengan baik pada diri seseorang 
pada saat menghadapi masalah yang harus dipecahkan.

Memecahkan masalah merupakan aktivitas mental tingkat tinggi, sehingga pengembangan keterampilan pemecahan masalah dalam pembelajaran matematika tidak mudah. Masalah dalam matematika sifatnya ada yang rutin maupun non rutin. Masalah rutin adalah masalah yang mudah diselesaikan dengan menerapkan rumus atau dalil dan prosedur yang sudah biasa diberikan atau contoh - contoh dalam buku cetak. Biasanya masalah rutin hanya melibatkan satu operasi matematik, sehingga permasalan yang dikemukakan sangat mudah diamati oleh mahasiswa.

Proses berpikir mahasiswa dalam memecahkan masalah matematika sangat penting untuk mendapat perhatian guru. Jika proses berpikir mahasiswa dapat diketahui, maka dapat mengungkap bagaimana proses yang berkembang dalam pikiran siswa ketika mereka memecahkan masalah. Banyak fakta yang terjadi tentang permasalahan terhadap pemecahan masalah dalam matematika, mulai dari jenjang pendidikan dasar, menengah sampai pendidikan tinggi.

Fenomena tentang kesulitan pemecahan masalah khususnya masalah masalah non rutin seperti contoh yang dikemukan diatas masih dialami kebanyakan mahasiswa jurusan PG-PAUD UHO. Dengan demikian diduga pemecahan masalah matematika mahasiswa dipandang perlu dikaji dalam suatu penelitian. Hal senada dari hasil wawancara salah satu dengan dosen jurusan PG-PAUD, diperoleh informasi bahwa mahasiswa masih sulit untuk menyelesaikan masalah matematika, khususnya yang berkaitan dengan masalah kehidupan sehari-hari. Lebih lanjut dosen yang bersangkutan mengatakan bahwa masalah yang sering dijumpai dalam pemecahan masalah adalah soal-soal yang berkaitan dengan himpunan.

Gaya kognitif belum menjadi pertimbangan dalam perencanaan pembelajaran yang dirancang oleh dosen. mahasiswa yang memiliki gaya kognitif yang berbeda cenderung menyelesaikan masalanya berbeda, dalam hal ini terdapat perbedaan proses berpikir. Perbedaan proses berpikir disebabkan banyak hal salah satunya adalah kemampuan mahasiswa dalam menerima dan memproses informasi yang telah diberikan oleh dosen ketika pembelajaran berlangsung yang biasa disebut gaya kognitif. Kemampuan memecahkan masalah matematika, termasuk ketelitian dan keterampilan setiap orang berbedabeda.

Pemecahan masalah didefinisikan sebagai usaha mencari jalan keluar dari suatu kesulitan untuk mencapai tujuan yang tidak dengan segera dapat dicapai (Polya, 1973). Pemecahan masalah merupakan perwujudan dari suatu aktivitas mental yang terdiri dari bermacam-macam keterampilan dan tindakan kognitif yang dimaksudkan untuk mendapatkan solusi yang benar (Kirkley, 2003). Hal ini akan berakibat pada kemampuan tiap-tiap orang dalam memecahkan masalah akan berbeda-beda. Solso, Maclin \& Maclin (2008) mengemukakan hal yang sama tentang pemecahan masalah yaitu suatu pemikiran yang terarah secara langsung untuk menemukan suatu solusi/jalan keluar dari suatu masalah yang spesifik.

Upaya untuk memecahkan masalah diperlukan berbagai tahapan pemecahan masalah. Salah satu tahapan pemecahan masalah matematika yang sering dirujuk adalah pentahapan Polya (1973), yang mengemukakan empat tahapan yang perlu dilakukan, yaitu: (a) memahami masalah; (b) membuat rencana penyelesaian; (c) melaksanakan rencana yang telah dibuat; (d) melihat ke belakang (looking back) atau memeriksa ulang jawaban yang diperoleh.

Berdasarkan dari pengertianpengertian pemecahan masalah yang dikemukakan di atas, dapat disimpulkan bahwa pemecahan masalah adalah suatu 
kegiatan untuk mencari jalan keluar dari suatu masalah yang ingin diselesaikan, namun tidak segera dapat ditemukan cara penyelesaiannya.

Membangun proses berpikir siswa dalam memecahkan masalah matematika, ada dua konsep penting dalam teori Vigotsky (Lambas, 2004), yaitu Zone of Proximal Development (ZPD) dan scaffolding. Zone of Proximal Development (ZPD) didefinisikan sebagai ruang antara tingkat perkembangan aktual dan tingkat perkembangan potensial. Tingkat perkembangan aktual adalah tingkat kemampuan anak untuk menyelesaikan masalah-masalah tertentu secara independen, sedangkan tingkat perkembangan potensial yaitu tingkat perkembangan yang dapat dicapai oleh anak jika anak yang bersangkutan mendapat bimbingan atau bantuan dari seseorang yang lebih dewasa atau lebih kompeten.

Pemberian scaffolding dalam penelitian ini, mengacu pada tingkatan 2 (dua) dan 3 (tiga) scaffolding yang dikemukakan Anghileri. Hal ini disebabkan karena pada tingkat 1 (satu) adalah environmental provisions, yaitu penataan lingkungan belajar, bermain bebas dan kerjasama dengan teman sebaya (cocok untuk anak SD atau TK). Poin-poin pada tingkatan 2 (dua) yaitu explaining, reviewing and restructuring, pada tingkatan ini siswa diminta memahami masalah, melakukan refleksi, memperbaiki jawaban dan menyusun kembali rancangan

\section{METODE PENELITIAN}

Penelitian ini adalah penelitian eksploratif yang bertujuan untuk mendeskripsikan proses berpikir mahasiswa Jurusan PG-PAUD dalam menyelesaikan masalah matematika dengan pemberian scaffolding oleh peneliti. Proses berpikir mahasiswa diamati dengan mencermati (mengkaji) hasil kerja mahasiswa dalam menyelesaikan suatu masalah matematika. jawabannya. Poin pada tingkat 3 (tiga) yaitu developing conceptual thinking, siswa diminta untuk mencari alternatif lain guna menyelesaikan masalah dan diskusi tentang jawaban yang telah dibuat siswa.

Gaya kognitif ditandai sebagai suatu sifat kognitif yang mungkin untuk menyatakan perbedaan kemampuan individu dalam kualitas pemecahan masalah. Pengukuran sifat tersebut biasanya melibatkan tugas yang membutuhkan pilihan solusi yang tepat di antara beberapa alternatif respon, dengan latency dan ketepatan respon dicatat untuk setiap item (Kagan, 1966). Gaya kognitif yang menjadi fokus dalam penelitian ini adalah gaya kognitif impulsif-reflektif yang dikemukakan Jerome Kagan tahun 1965.

$\begin{array}{ccc}\text { Kagan (1965) } & \text { menjelaskan bahwa } \\ \text { gaya } & \text { kognitif } & \text { impulsif-reflektif }\end{array}$ menggambarkan kecenderungan seseorang yang tetap dalam menunjukkan cepat atau lambat waktu menjawab terhadap situasi masalah dengan ketidakpastian jawaban yang tinggi. Menurut Kagan (1965), anak yang memiliki karakteristik cepat dalam menjawab masalah, tetapi tidak cermat sehingga jawaban masalah cenderung salah, disebut bergaya kognitif impulsif, sedangkan anak yang memiliki karakteristik lambat dalam menjawab tetapi cermat, sehingga jawaban masalah cenderung betul, disebut bergaya kognitif reflektif.

Apabila mahasiswa terhambat/kesulitan dalam memecahkan masalah matematika, peneliti mengajukan pertanyaan atau pernyataan untuk memberikan bantuan (scaffolding) pada mahasiswa, supaya mahasiswa dapat melanjutkan penyelesaian masalah yang dihadapinya.

Pemilihan subjek penelitian ini mengacu pada tujuan penelitian, yaitu untuk mengungkapkan proses berpikir 
mahasiswa dalam memecahkan masalah matematika dengan pemberian scaffolding ditinjau dari gaya kognitif.

Proses pemilihan subjek penelitian diawali dengan meminta informasi dari dosen tentang mahasiswa yang cepat menyelesaikan soal tetapi cenderung banyak salahnya dan mahasiswa yang lambat menyelesaikan soal tetapi cenderung sedikit salahnya. Selanjutnya dilakukan pemberian tes gaya kognitif, kemudian dipilih kelompok mahasiswa yang bergaya kognitif impulsif dan kelompok mahasiswa yang bergaya kognitif reflektif. Untuk menentukan subjek penelitian dari setiap kelompok mahasiswa yang bergaya kognitif impulsif dan yang bergaya kognitif reflektif. Adapun kriterianya sebagai barikut: (1) kelompok impulsif diambil dari mahasiswa yang catatan waktunya paling cepat dan tidak cermat/banyak kesalahan dalam menjawab, dan kelompok reflektif diambil dari mahasiswa yang catatan waktunya cenderung paling lama dan cermat/sedikit kesalahan; (2) mampu mengkomunikasikan pendapat/jalan pikirannya secara lisan atau tertulis; (3) semua subjek yang dipilih memiliki kemampuan matematika relatif sama.

Instrumen dalam penelitian ini ada dua macam, yaitu instrumen utama dan instrumen bantu. Insrumen utama adalah peneliti sendiri, sedangkan instrumen bantu ada 3 (tiga) macam, yaitu: tes gaya kognitif (MFFT), tugas pemecahan masalah (TPM) dan pedoman wawancara.

Instrumen bantu dalam penelitian ini terdiri atas tiga yaitu bantu 1 ( tes gaya kognitif), instrument bantu II ( tugas pemecahan masalah matematik) dan instrument bantu III ( pedoman wawancara). Untuk mengumpulkan data dalam penelitian ini, akan digunakan teknik pemberian tes dan wawancara. Analisis data dalam penelitian ini mengikuti model analisis Miles dan Huberman (Sugiyono, 2008), yang mengikuti proses: (1) reduksi data, (2) penyajian data dan (3) penarikan kesimpulan

\section{HASIL PENELITIAN}

Subjek Pertama Impulsif (S1I)

\section{Tahapan}

Polya

Memahami masalah
(1) Memahami masalah dengan cara membaca masalah beberapa kali sampai masalah itu benar-benar dipahami dengan baik, kemudian menyajikan pernyataan lisan tentang apa yang dipahami. Menyatakan dan mengungkapkan secara lisan apa yang diketahui pada masalah. (3) Menyatakan dan mengungkapkan secara lisan apa yang ditanyakan pada masalah. (4) Tidak memyatakan yang diketahui pada masalah, dapat memudahkan penyelesaian masalah.

Merencanakan (1) menggunakan operasi himpunan untuk menyelesaikan masalah. (2) masalah

Mengungkapkan cara yang
$n(S)=n(A)+n(B)-n(A \cap B)+n(A \cup B)^{C}$

(3) Mengemukakan alasan menggunakan seperti cara yang diungkapkan. (4) Mengemukakan secara lisan langkah-langkah memecahkan masalah. (5) Menyatakan secara lisan kebenaran rencana memecahkan masalah.

Melaksanakan (1) Menyatakan secara lisan bahwa sudah mempunyai ide untuk rencana menyelesaikan masalah. (2) Pada awal melaksanakan rencana, mengalami masalah dalam proses penyelesaian. (3) Diberikan pertanyaan atau pernyataan dengan harapan bisa melanjutkan penyelesaian masalah. (4) Menyadari langkah yang dilakukan terdapat 


\begin{tabular}{ll}
\hline & kekeliruan, sehingga mengulang menyelesaiakna masalah. (5) \\
& Menyelesaiakan masalah tetap menggunakan operasi himpunan, seperti \\
& yang diungkapkan sebelumnya. (6) Dalam melaksanakan rencana, \\
& terdapat kekeliruan. (7) Pada hasil akhir melaksanakan rencana, jawaban \\
& tidak benar. (8) Tetap meyakini bahwa penyelesaiannya yang telah \\
dibuat adalah benar. & (1) Mengungkapkan cara memeriksa kembali hasil pemecahan masalah, \\
Mengecek & yaitu mengecek hasil pekerjaannya setiap tahap, dengan operasi \\
kembali & himpunan yang dituliskan sebelumnya. (2) menyimpulkan dari \\
& mengecek hasil pekerjaannya. (3) Menyatakan tidak ada cara lain yang \\
& tujuannya sama untuk mengecek hasil pekerjaannya. \\
\hline
\end{tabular}

Subjek Kedua Reflektif (S2R)

\begin{tabular}{|c|c|}
\hline $\begin{array}{c}\text { Tahapan } \\
\text { Polya }\end{array}$ & Hasil Temuan \\
\hline $\begin{array}{l}\text { Memahami } \\
\text { masalah }\end{array}$ & $\begin{array}{l}\text { (1) Membaca masalah dalam hati beberapa kali sampai masalah } \\
\text { dipahami dengan baik. (2) Mengungkapkan secara lisan tentang apa } \\
\text { yang dipahami pada masalah ketika memahami masalah. (3) } \\
\text { Mengungkapkan hal yang diketahui secara rinci dan yang ditanyakan } \\
\text { pada masalah. (4) Menyatakan kebenaran tentang apa yang } \\
\text { diungkapkan dan yang dituliskan pada masalah. }\end{array}$ \\
\hline $\begin{array}{l}\text { Merencanakan } \\
\text { masalah }\end{array}$ & $\begin{array}{l}\text { (1) menggunakan operasi himpunan untuk menyelesaikan masalah. (2) } \\
\text { Mengungkapkan cara yang digunakan adalah } \\
n(S)=n(A)+n(B)-n(A \cap B)+n(A \cup B)^{C} \quad \cdot \quad \text { (3) Mengemukakan alasan } \\
\text { menggunakan seperti cara yang diungkapkan. (4) Mengemukakan } \\
\text { secara lisan langkah-langkah memecahkan masalah. (5) Menyatakan } \\
\text { secara lisan kebenaran rencana memecahkan masalah. }\end{array}$ \\
\hline $\begin{array}{l}\text { Melaksanakan } \\
\text { rencana }\end{array}$ & $\begin{array}{l}\text { (1) Menyatakan secara lisan bahwa sudah mempunyai ide untuk } \\
\text { menyelesaikan masalah. (2) Pada awal melaksanakan rencana, } \\
\text { mengalami masalah dalam proses penyelesaian. (3) Diberikan } \\
\text { pertanyaan atau pernyataan dengan harapan bisa melanjutkan } \\
\text { penyelesaian masalah. (4) Menyadari langkah yang dilakukan terdapat } \\
\text { kekeliruan, sehingga mengulang menyelesaiakna masalah. (5) } \\
\text { Menyelesaiakan masalah tetap menggunakan operasi himpunan, seperti } \\
\text { yang diungkapkan sebelumnya. (6) Dalam melaksanakan rencana, } \\
\text { terdapat kekeliruan. (7) Pada hasil akhir melaksanakan rencana, } \\
\text { jawaban tidak benar. (8) Tetap meyakini bahwa penyelesaiannya yang } \\
\text { telah dibuat adalah benar. }\end{array}$ \\
\hline $\begin{array}{l}\text { Mengecek } \\
\text { kembali }\end{array}$ & $\begin{array}{l}\text { (1) engungkapkan cara memeriksa kembali hasil pemecahan masalah. } \\
\text { (2) Memeriksa kembali hasil pemecahan masalah menggunakan cara } \\
\text { lain selain cara yang digunakan dalam memecahkan masalah. (3) } \\
\text { Menyatakan kebenaran hasil pemecahan masalah yang diperoleh. }\end{array}$ \\
\hline
\end{tabular}

\section{PEMBAHASAN}

Berdasarkan hasil analisis pada bagian sebelumnya, dikemukakan pembahasan tentang proses berpikir mahasiswa dalam memecahkan masalah matematika dengan scaffolding
berdasarkan pentahapan Polya.
Dari cuplikan hasil wawancara
terlihat jelas bahwa subjek impulsif tidak 
cermat dalam menyelesaikan masalah yang diberikan. Hal ini dapat di lihat dari jawaban subjek pada saat dilakukan wawancara berbasis tugas, hasil pekerjaan banyak yang dicoret yang disebabkan karena tidak cermat/tidak teliti pada saat menyelesaikan masalah matematika yang diberikan. Sedangkan subjek bergaya kognitif reflektif tampak cermat dan lebih teliti pada saat dilakukan wawancara berbasis tugas. gambaran proses berpikir subjek dalam penelitian ini, akan dibahas proses berpikir mereka pada setiap tahap pemecahan masalah sesuai pentahapan Polya.

Pada tahap memahami masalah, subjek impulsif pertama membaca masalah hanya dilakukan dua kali, sehingga mengakibatkan subjek impulsif diduga kurang cermat memahami masalah, hal ini terlihat pada tahap menyelesaikan akan sangat terlihat pemahaman pada masalah. sedangkan subjek reflektif dalam memahami masalah membaca secara berulang-ulang. Sebagaimana pendapat yang dikemukakan Mubarik dalam Nurhayati (2013:9) bahwa pembacaan secara berulang-ulang menunjukkan masalah yang diberikan menjadi masalah bagi peserta didik tersebut karena tidak dapat langsung memahami dan menemukan cara penyelesaian dari masalah yang diberikan. Berdasarkan pengamatan peneliti, kedua subjek tetap mampu menyatakan hal diketahui pada masalah, hal yang ditanyakan pada masalah serta mampu mengungkapkan apa yang dipahami pada masalah, sebagaimana yang dikemukakan oleh Polya (Nurhayati, 2013:8) maksud dari tahap pemahaman masalah ialah bahwa peserta didik harus dapat memahami kondisi soal atau masalah yang ada pada soal tersebut. Menurutnya, ciri bahwa siswa paham terhadap isi soal ialah peserta didik dapat mengungkapkan pertanyaan-pertanyaan beserta jawabannya

Dari Uraian-uraian tersebut memberikan gambaran bahwa baik subjek
(S1) Impulsif maupun Subjek (S2) Reflektif pada tahap memahami masalah tergolong tipe proses berpikir konseptual.

Pada tahap membuat rencana pemecahan masalah, kedua subjek membuat rencana pemecahan masalah berdasarkan apa yang diketahui dan yang ditanyakan pada tahap sebelumnya. Subjek menyiapkan rencana penyelesaian; mengungkapkan secara rinci langkahlangkah penyelesaian masalah; menyatakan dan yakin bahwa yang dipikirkan pada rencana pemecahan masalah sudah benar. Menurut Polya dalam Nurhayati (2013:10) dalam tahap pemikiran suatu rencana, peserta didik harus dapat memikirkan langkah-langkah apa saja yang penting dan saling menunjang untuk dapat memecahkan masalah yang dihadapinya. Pada tahap ini kedua subjek menyatakan akan menentukan banyaknya anggota himpunan dengan operasi himpunan yakni $n(S)=n(A)+n(B)-n(A \cap B)+n(A \cup B)^{C}$.

Dalam hal ini peneliti tidak mengarahkan untuk mengubah langkah yang dipilih oleh subjek karena langkah yang digunakan sudah dipelajari dan tepat juga untuk memecahkan masalah yang diberikan. Semua subjek menyatakan yakin dengan rencana yang telah dibuat untuk memecahkan masalah ini. Pada tahap merencanakan pemecahan masalah kedua subjek cenderung tipe proses berpikir konseptual.

Pada tahap melaksanakan rencana pemecahan masalah, kedua subjek baik impulsif maupun reflektif menuliskan rencana yang telah dibuat. Pada tahap ini terlihat proses berpikir subjek yang sebenarnya. Scaffolding diberikan pada subjek implusif karena kebingungan melanjutkan penyelesaian yang diakibatkan kekeliruan. Pada masalah 1 subjek impulsif keliru menggunakan operasi himpunan, sementara pada masalah 2 subjek impulsif keliru pada pertukaran kedua ruas. Namun setelah diberikan scaffolding subjek impulsif 
mampu melanjutkan penyelesaiannya dengan benar. Sedangkan subjek reflektif pada tahap melaksanakan rencana juga diberikan scaffolding, karena tidak mampu melanjutkan rencana yang telah dibuatnya dan melakukan sesuai yang diungkapkan pada tahap merencanakan pemecahan masalah. Dengan demikian subjek reflektif cenderung tipe proses berpikirnya adalah semikonseptual sedangkan subjek impulsif proses berpikirnya cenderung konseptual sekalipun harus diberikan scaffolding dalam melaksanakan rencana penyelesaian masalah. Namun scaffolding pada subjek implusif yang menyebabkan perubahan proses berpikirnya, tidak dalam artian berubah gaya kognitifnya, karena

\section{KESIMPULAN DAN SARAN}

Berdasarkan hasil penelitian dan pembahasan, maka kesimpulan dalam peneleitian ini adalah sebagai berikut: (1) Tahap memahami masalah: kedua subjek penelitian (impulsif dan reflektif) mampu mengungkapkan yang diketahui dan ditanyakan pada masalah, mampu menyatakan yang dipahami dalam masalah, mampu menyebutkan syarat yang diperlukan untuk menyelesaikan masalah. Kedua subjek pada tahap ini cenderung memiliki tipe proses berpikir konseptual. (2) Tahap membuat rencana pemecahan masalah: kedua subjek penelitian (impulsif dan reflektif) membuat rencana memecahkan masalah yaitu dengan menggunakan operasi himpunan dan diagram venn. Pada tahap ini semua subjek cenderung proses berpikirnya konseptual. (3) Tahap melaksanakan rencana pemecahan masalah: kedua subjek penelitian (impulsif dan reflektif) mengemukakan ide secara tertulis untuk memecahkan masalah, subjek reflektif dan subjek impulsif diberikan scaffolding agar dapat melanjutkan penyelesaian. Pada tahap ini perubahan cara pikir hanya karena scaffolding dimana cukup efektif untuk subjek pada masalah ini.

Pada saat memeriksa kembali hasil pemecahan masalah, kedua subjek penelitian mengungkapkan cara memeriksa kembali hasil pemecahan masalah yang telah dibuat. Kedua subjek menelusuri/mengecek ulang langkahlangkah pemecahan masalah yang telah dituliskan pada penyelesaian dengan menggunakan diagram venn mengungkapkan hasilnya, sehingga subjek yakin dengan hasil pemecahan masalah yang telah dibuat. Kedua subjek dapat dikatakan proses berpikirnya cenderung konseptual.

subjek cenderung tipe berpikirnya semikonseptual. (4) Tahap memeriksa kembali hasil pemecahan masalah: kedua subjek penelitian (impulsif dan reflektif), memeriksa hasil pemecahan masalah dengan menelusuri hasil pemecahan masalah yang telah dibuat dengan menggunakan diagram venn sesuai dengan perencanaan. Pada Tahap ini kedua subjek cenderung tipe berpikirnya konseptual.

Berdasarkan kesimpulan di atas, maka peneliti menyarankan beberapa hal berikut: (1) Dalam menetapkan mahasiwa pada suatu kelas sebaiknya mengelompokannya dengan gaya kognitif yang cenderung sama. (2) Scaffolding dalam pembelajaran harus disiapkan dan dilakukan oleh pengajar, karena sangat membantu ketika proses berpikirnya terhenti pada tahap-tahap tertentu dalam memecahkan masalah-masalah matematika. (3) Penelitian ini dapat menjadi masukan sekaligus dapat menjadi acuan pada penelitian-penelitian selanjutnya agar penelitian mengenai gaya kognitif ini menjadi lebih baik. 


\section{DAFTAR PUSTAKA}

Agustina, Tria.2013. Pengaruh Pemberian Bantuan (Scaffolding) pada Aktivitas Belajar Menggunakan Model Penemuan Terbimbing Terhadap Hasil Belajar Fisika Siswa SMA. Skripsi Tidak Diterbitkan. Malang: FKIP Universitas Negeri Malang.

Goleman, Daniel. 2007. Emotional Intelligence: Mengapa EQ Lebih Penting daripada IQ (Terjemahan oleh: Hermaya), Jakarta, Gramedia Pustaka Utama

Kagan, Jerome. 1965. Impulsive and Reflektive Children Significance of Conceptual Tempo. Dalam Krumboltz, J.D (Edt) Learning and the Educational Process. Chicago, Mc Nally \& Company.

Kirkley, J. 2003. Principle for Teaching Problem Solving, Technical Paper, Plato Learning Inc.

Krutetskii. 1976. The Psychology of Mathematics Abilities in School Children, USA, University of Chicago.

Lambas. 2004. Materi Pelatihan Terintegrasi. Jakarta: Departemen Pendidikan Nasional Direktorat Jen-dral Pendidikan Dasar dan Menen-gah Direktorat Pendidikan Lanju-tan Pertama.

Polya, G. 1973. How To Solve It, Second Edition, New Yersey, Princeton University Press.

Solso, Robert L., Maclin Otto H., \& Maclin M. Kimberly. 2008. Kognitive Psycchology (Alih Bahasa: Mikael Rahardianto dan Kristianto Batuadji), Jakarta, Penerbit Erlangga.

Sudia, Muhammad. 2013. Profil Metakognisi Siswa SMP yang Bergaya Kognitif Impulsif-Reflektif dalam Memecahkan Masalah Terbuka Materi Geometri Ditinjau dari Perbedaan Gender. Disertasi (Tidak dipublikasikan), PPS-Unesa, Surabaya.

Sugiyono. 2008. Metode Penelitian Kuantitatif-Kualitatif dan $R \& D$, Bandung, Alfabeta. 